\title{
Chronic verrucous varicella zoster virus skin lesions: clinical, histological, molecular and therapeutic aspects
}

\author{
Nikkels A. F ${ }^{[1]}$, Snoeck R [3], Rentier B. ${ }^{[2]}$ Pierard G E ${ }^{[1]}$ \\ ${ }^{[1]}$ Department of Dermatopathology, University of Liege, Belgium \\ $[2]_{\text {Fundamental Virology, University of Liege, Belgium }}$ \\ $[3]_{\text {REGA Institute, University of Leuven, Belgium }}$
}

\section{Summary}

The outbreak of HIV infection introduced a new phenomenon in varicella zoster virus (VZV) pathology, namely the long-standing wart-like skin lesions that are frequently associated with resistance to thymidine kinase (TK)-dependent antiviral agents. This paper reviews the clinical, histological, and molecular aspects and the therapeutic management of these verrucous lesions. The majority of lesions are characterized by chronically evolving, unique or multiple wart-like cutaneous lesions. The main histo-pathological features include hyperkeratosis, verruciform acanthosis and VZVinduced cytopathic changes with scant or absent cytolysis of infected keratinocytes. The mechanism that establishes the chronic nature of the lesions appears to be associated with a particular pattern of VZV gene expression exhibiting reduced or nondetectable $\mathrm{gE}$ and $\mathrm{gB}$ synthesis. Drug resistance to TKdependent antiviral agents is a result of nonfunctional or deficient viral TK. This necessitates alternative therapeutic management using antiviral agents that target the viral DNA polymerase.

\section{Introduction}

The varicella-zoster virus (VZV) is the infectious agent responsible for chickenpox and shingles. ${ }^{1}$ Following initial contact with the upper respiratory tract and/or the conjunctiva and two successive viremic phases, the VZV virus produces the characteristic varicella eruption. Subsequently, it establishes a latent infection in dorsal root ganglia. Years later, VZV can reactivate and follow an antidromic axonal return from the dorsal root ganglia to the skin where herpes zoster develops in the corresponding dermatome(s). , $^{2,3}$

As it is prone to cutaneous and/or visceral dissemination in the immunocompromised population, the virus is associated with a marked rate of morbidity and mortal-ity. ${ }^{4-6}$ The same agent is also capable of producing atypical cutaneous lesions and the spectrum of new skin manifestations is expanding. ${ }^{7}$ Besides the hyperkeratotic VZV skin lesions that represent the most frequently encountered atypical phenomenon, lichenoid reactions ${ }^{8,9}$ and follicular herpes zoster ${ }^{10-12}$ have recently been described. In the 1980 s, the first reports of long-standing or chronic VZV infections appeared. ${ }^{4,13}$ Precise data regarding the incidence and prevalence of such lesions in HIV-infected patients and in organ transplant recipients are not available. However, due to their atypical features, they probably remain quite frequently unrecognized. Currently, the majority of the cases are found in HIV-infected patients with low CD4 cell counts; however, cases have occasionally been observed in organ transplant recipients. ${ }^{14-}$ ${ }^{30}$ In general, the lesions the most florid and characteristic in patients with low CD4 cell counts. Because the administration of triple therapy for AIDS prevents the occurrence of low CD4 cell counts, the recognition of these lesions may become even less certain.

Chronic verrucous lesions differ from stereotypic varicella and herpes zoster lesions in many aspects. In addition to their atypical clinical manifestations, different diagnostic methods may be required, the histopathological features are heterogenous, and the pathogenesis of the lesion is peculiar. The therapeutic approach also differs compared with the management of classic VZV infections in the immunocompomised host. ${ }^{31-35}$

\section{Clinical aspects}


The vast majority of verrucous VZV occurs in HIV-infected patients with low CD4 cell counts. ${ }^{14-30}$ However, some cases have been described in patients under immunosuppressive regimens for organ transplanta-tion. ${ }^{7}$ and the entity has occurred in an immunocompe-tent patient. ${ }^{36}$ No particular sex ratio or racial predilection appears to exist. Individuals aged 4-48 years can be affected. ${ }^{13-30,37-41}$ Although there is a significant clinical polymorphism of chronic verrucous VZV lesions, the typical presentation consists of single or multiple pox-like or wart-like hyperkeratotic and well demarcated lesions which vary from $4 \mathrm{~mm}$ to $10 \mathrm{~cm}$ in diameter (Fig. 1). ${ }^{26}$ Any site of the body surface can be affected and, although some patients can experience pain, complaints of discomfort are generally absent. ${ }^{20-23}$
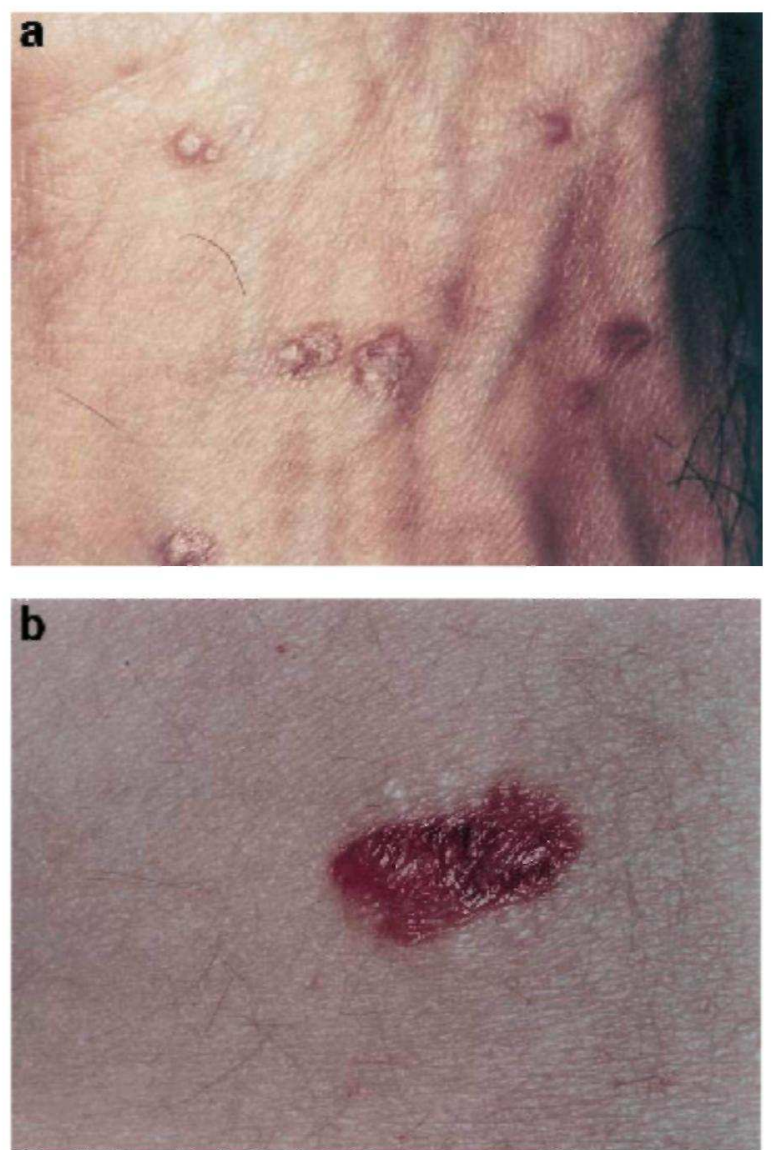

Figure 1 (a) Multiple verrucous VZV lesions on the dorsum of the hand. (b) Single verrucous VZV lesion on the abdomen.

The lesions usually persist from several weeks to months and present periods of extension or regression without healing completely. ${ }^{14-30}$ In some cases, the hyperkeratosis vanishes and chronic, indolent and necrotic ulcerations manifest. ${ }^{13,20,26}$ Verrucous zoster responsive to antiviral treatment usually clears in about 2-3 weeks. Atrophic, varicella-like scarring may occur after healing. Relapses of verrucous lesions after successful therapy are possible and may affect either the same or another site.

In these immunosuppressed patients, several clinical situations can preceed the development of chronic VZV verrucous lesions. Initially, verrucous lesions can follow varicella, particularly in children. ${ }^{26,42}$ In this instance, the varicella skin lesions show no tendency towards healing and progressively take on a wart-like appearance.

Secondly, verrucous lesions can develop directly from shingles. ${ }^{14-30}$ These predominantly adult patients suffer a zosteriform eruption that does not resolve but slowly progresses to hyperkeratotic nodules. Thirdly, the lesions can occur in subjects showing no evidence of classic herpes zoster ${ }^{20}$ and are probably derived from haematogenous dissemination after dorsal root ganglia reactivation without dermatomal involvement.

The clinical differential diagnosis includes molluscum contagiosum, ${ }^{30,42}$ basal cell carcinoma ${ }^{14}$ and occasionally the lesions may resemble ecthyma gangrenosum or disseminated deep fungal infection. Chronic VZV infection may also affect extracutaneous sites, causing chronic myelitis without 
cutaneous eruption $^{43}$ and chronic ocular herpes zoster. ${ }^{44}$

\section{Histology}

Like the clinical presentation, the histopathological features of chronic verrucous zoster are often hetero-genous (Fig. 2). ${ }^{22,45}$ However, the typical wart-like lesions are basically similar and they are characterized by a massive orthokeratotic hyperkeratosis, sometimes accompanied by the presence of parakeratotic columns. The epidermis exhibits varying degrees of papillomatous verrucous, sometimes even pseudo-epitheliomatous hyperplasia. ${ }^{21,22}$ The papillomatosis extends into the papillary dermis and even deeper into the reticular dermis. Occasionally, the adnexal structures also participate in the epithelial hyperplasia.

A variable degree of viral cytopathic changes are observed. The nuclear changes include the presence of multiple steel-grey appearing nuclei and Cowdry type A nuclear inclusions. Necrotic keratinocytes are observed as well as slightly swollen, eosinophilic cells lacking signs of cytolysis. ${ }^{21,45}$

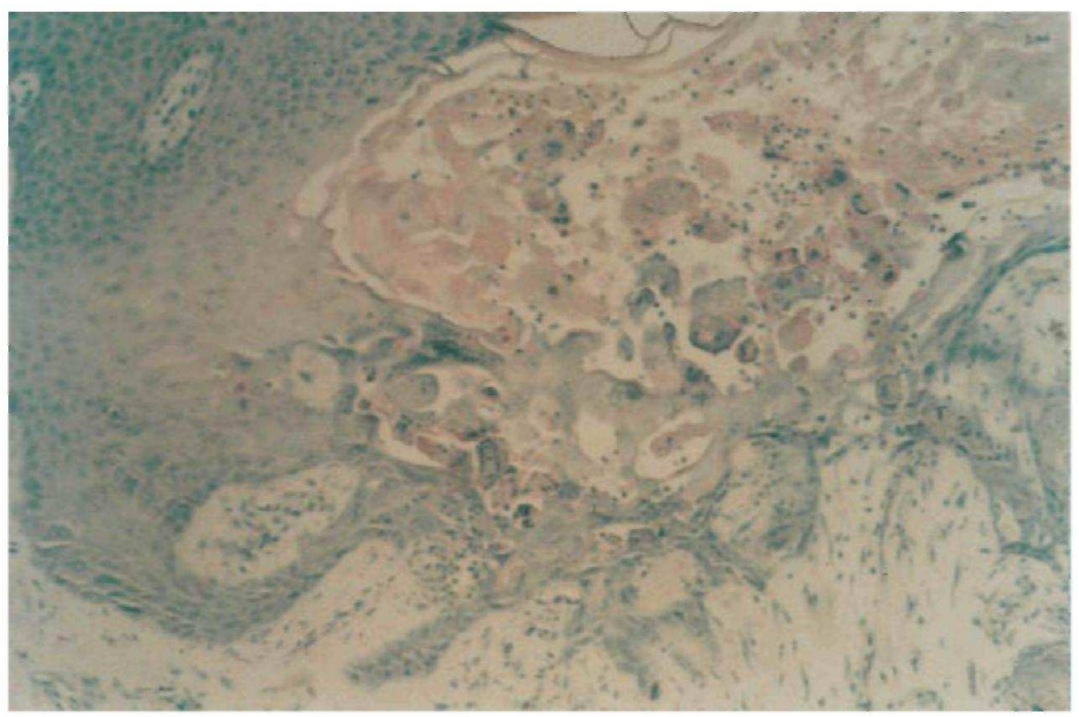

Figure 2 Histological appearance of a verrucous VZV lesion (x 200).

This latter feature is at variance with classic VZV infection in keratinocytes where cytolysis is a principal feature. ${ }^{10,45}$ These alterations are observed most frequently in the granular layer.

In some lesions, signs of alpha-herpesviridae-induced histopathological changes are not observed and the diagnosis can easily be overlooked. In the absence of viral cytopathic changes, keratoacanthoma and verru-cous carcinoma should be ruled out.

An inflammatory response of neutrophils and lymphocytes infiltrating the dermis and/or the hyperplastic epidermis is occasionally observed; however, in the majority of cases there is a lack, or only minimal, inflammatory infiltrate.

\section{Pathogenesis}

VZV has been determined as the sole pathogenic agent in chronic verrucous lesions. ${ }^{14-28,45}$ The presence of other DNA viruses, such as poxviruses, herpes simplex virus (HSV), Epstein-Barr virus or cytomegalovirus in chronic verrucous lesions, has previously suggested that this manifestation is not virus-specific. ${ }^{29}$ However, as the reports of VZV-associated cases greatly outnumber those of other viruses, and as the features are clearly distinctive, the majority of authors favour the hypothesis that it is a typical VZV-associated phenomenon. ${ }^{14-28,45}$ 


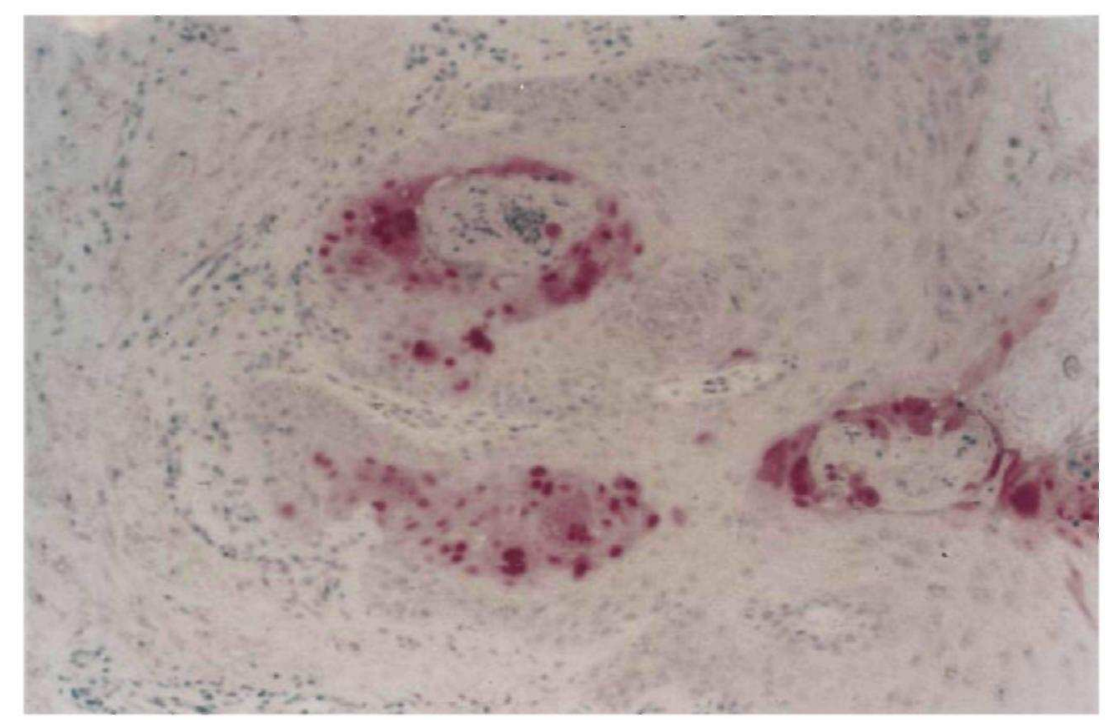

Figure 3 IE63 immunostaining in the nucleus of infected keratinocytes of a verrucous lesion (polyclonal anti-IE63 antibody, 1/250) (x 200). ${ }^{47}$

A possible coinfection with human papillomaviruses, suspected by the hyperkeratotic character of the lesions, has been ruled out. ${ }^{22}$

In AIDS patients, VZV skin infections may vary from verrucous lesions, in which viral synthesis appears to be strongly attenuated or even absent, ${ }^{45}$ to full-blown viral replication represented clinically by herpes zoster or chickenpox lesions. Hence, the clinical polymorphism and the wide spectrum of VZV skin manifestations might depend upon a particular pattern of VZV gene expression which can vary in concert with fluctuations in the immune status seen in AIDS patients. However, the exact influence of the host defence system in the pathogenesis of verrucous zoster is not clear, as the occurrence of identical lesions has been observed in immunocompetent, ${ }^{36}$ iatrogenic immunosuppressed ${ }^{17}$ and AIDS patients. ${ }^{14-29}$

The VZV replicative cycle is organized in a cascade involving three successive phases, namely the immediate-early (IE), early (E), and late (L) stages. ${ }^{1,3}$ After the attachment of the virus to the host cell membrane, the nucleocapsid is released into the host cell cytoplasm as well as proteins from the tegumentum lying between nucleocapsid and envelope. These proteins migrate to the nucleus along with the viral DNA released from the nucleocapsid and trigger the first phase of viral transcription. During the IE phase, IE genes are expressed and IE proteins are synthesized; the latter playing an important role in the establishment of latency in the dorsal root ganglion. Only some IE gene products, such as IE4, IE62, and IE63, and an E gene product called major DNA binding protein (MDBP) have been identified during latency in the dorsal root ganglion. ${ }^{46-50}$ It remains unknown which factors are responsible for maintaining the virus in the latent state, or activating its complete replicative cycle. In the early phase, E proteins, such as MDBP, DNA-polymerase and thymidine kinase (TK) are produced. The E gene products play key roles in the synthesis of new viral DNA.

During the late phase, L proteins, such as the viral envelope glycoproteins gE, gB, gC, gD, gH and gI, are synthesized. ${ }^{1}$ Subsequently, the newly formed nucleo-capsids become enveloped particles at the level of the cell nuclear membrane and are transported to the plasma membrane in large vacuoles where they are released from the cell by reverse phagocytosis.

In the usual VZV infection of keratinocytes, IE, E, and L gene products are abundantly synthesized. These infected cells display typical cytopathic changes. ${ }^{45}$ The intensity of viral replication probably plays a role in host cell death. In addition, recent in vitro ${ }^{51}$ and in vivo (unpublished results) data also favour the involvement of apoptosis.

The altered immune environment possibly creates a different relationship between the keratinocyte and VZV, leading to aberrant gene expression such as absent or changed viral TK synthesis (see

Mechanisms of drug resistance) and/or reduced or undetectable L protein synthesis. Whether these different expression patterns are invariably associated or individually regulated remains unknown. The pathogenesis of the chronic course and the near absence of cytolysis in verrucous VZV lesions remains unclear. An absent or reduced synthesis of $\mathrm{L}$ proteins $\mathrm{gB}$ and $\mathrm{gE}$ was found in noncytolytic keratinocytes using semiquantative immunohistochemical assessment of chonic verrucous VZV lesions in AIDS patients. ${ }^{45}$ In contrast, a strong immunohistochemical signal for the IE63 gene product could 
be demonstrated in all lesions (Fig. 3). It has been postulated that a decreased level of viral synthesis enables the host cell to survive and that a nonpermissive, chronic viral infection is established. Another histological characteristic of verrucous zoster is the near absence of inflammatory infiltrate. Considering the prominent immunogenic properties of the envelope proteins $\mathrm{gE}$ and $\mathrm{gB}$, it is conceivable that the paucity or absence of these major immunogenic glyco-proteins on the host cell membrane limits MHC class I-associated antigen presentation to the CD8 cytotoxic immune system which is already impaired in AIDS patients. Another mechanism that assists the virus to evade the host immune response may be inhibition of MHC class I antigen expression. ${ }^{52}$ The silencing of host cell immune responsiveness together with the reduced level of viral synthesis is a plausible explanation for the chronicity of the lesions.

The other alpha-herpesviruses, HSV 1 and HSV 2, are also capable of causing chronic cutaneous infections. ${ }^{53-55}$ There is, however, only one single case report that matches the clinical and histological features of chronic VZV verrucous lesions. ${ }^{56}$ Extracutaneous chronic disease, such as a HSV chronic laryngitis in an AIDS patient ${ }^{57}$ and chronic meningitis due to HSV in an immunocom-petent host ${ }^{58}$ has been reported. As with VZV verrucous lesions, the precise intervention of the immune system in the developmentofthe HSV chronic lesions, asdescribed in immunocompetent ${ }^{58}$ and immunosuppressed patients, ${ }^{57}$ is not clear. Although unproven, the pathogenic mechanisms of chronic HSV skin lesions and of extra-cutaneous chronic VZV and HSV lesions could be similar to those proposed for cutaneous chronic VZV eruptions.

\section{Diagnostic methods}

\section{Skin biopsy}

The diagnosis of the hyperkeratotic VZV lesions is rooted in the recognition of the above-described histopathologi-cal features from a skin biopsy. Although most of the cases are associated with the VZV virus, HSV type 1 or 2 infection shouldberuled out using immunohistochemistry or in situ hybridization. These methods are also mandatory to prove the viral origin when histopathological signs of VZV cytopathology are absent. As altered viral gene expression may be observed, immunohistochemical screening for VZV should preferentially include antibodies directed against VZV IE and L gene products. ${ }^{45}$

\section{Viral culture}

In viral culture from clinical specimens, VZV is more difficult to recover than HSV. Furthermore, viral culture is of little use as a rapid diagnostic tool. TK-deficient VZV strains, frequently observed in chronic verrucous lesions, are known to be even more challenging to grow in culture. On the other hand, the hyperkeratotic character of the lesions does not easily permit sampling for culture. Hence viral culture is not the ideal diagnostic tool with which to identify VZV in these lesions. However, when drug resistance occurs, viral culture remains absolutely necessary for drug susceptibility testing. ${ }^{59}$

\section{Tzanck smear}

Due to the difficulty of sampling, the Tzanck smear is not a useful diagnostic tool in the presence of hyperkeratotic lesions. However, in ulcerated lesions, an immunohisto-chemically based differential diagnosis can be obtained from a smear. ${ }^{60}$ Again, the indolent and nonflorid character of the lesions do not favour the retrieval of enough material to reach a diagnosis.

\section{Electron Microscopy}

Intranuclear viral particles consistent with VZV infection in keratinocytes have been identified by electron micro-scopy. ${ }^{21,22,61,62}$ As distinction between VZV and HSV is not possible by ultrastructural morphology, electron microscopy should be considered only as a complementary diagnostic aid. 
Relapse of VZV infection in AIDS patients that requires frequent, long-term maintenance, and often low-dose, suppressive acyclovir (ACV) treatment, ${ }^{63}$ may result in ACV-resistance. ${ }^{1,23,2,64-67}$ Chronic verrucous zoster is frequently associated with ACV-resistance. ${ }^{20,37,62}$ The mutations leading to resistance are located at the level of the viral TK, a 35-kDa protein with both thymidine and thymidylate phosphorylating properties. It possesses an overall sequence identity of $\approx 28 \%$ with HSV TK.

To be active, ACV must be phosphorylated three times. The viral TK is responsible for the first phosphorylation of ACV and the two subsequent phosphorylations are performed by TK encoded by the host cell. Sequencing of the TK gene of drug resistant VZV strains has revealed nucleotide deletions or insertions that introduce a premature termination codon; this probably leads to the synthesis of a truncated, nonfunctional TK protein. These may occur at various positions in the protein, such as in the conserved nucleotide (ATP) binding site, in the nucleoside (substrate) binding site, between the binding sites and at the $\mathrm{C}$-terminal end of the protein. ${ }^{69}$ These alterations lead to loss of enzymatic activity and confer resistance to TK-dependent drugs. Cross-resistance between TKdependent drugs such as ACV, penciclovir, $882 \mathrm{C}$ and BV-ara-U in in vitro drug susceptibility assays occurs in most instances, but when resistance is suspected clinically, the use of another TK-dependent drug may be considered.

Occasionally, changes in the DNA polymerase gene are observed, conferring resistance to DNA polymerase inhibitors such as phosphoformic acid (foscarnet, PFA) and vidarabine. As for TKdependent drugs, cross-resistance between DNA polymerase inhibitors is not always found: this is illustrated by successful intravenous PFA treatment $(40 \mathrm{mg} / \mathrm{kg}$ per $8 \mathrm{~h}$ for 7 days) in progressive vidarabine-resistant $\left(10 \mathrm{mg} / \mathrm{kg}\right.$ per day), ACV-resis-tant HSV infection in a patient with AIDS. ${ }^{70}$ However, clinical resistance to PFA (6-to $15 \mathrm{~g}$ per day, i.v.) associated with in vitro PFA resistance has also been described in a HIV-infected woman with recurrent and chronic multidermatomal shingles. ${ }^{71}$

\section{Treatment}

The therapeutic approach to verrucous VZV lesions differs from the management of usual VZV infections in the immunocompromised population, ${ }^{63}$ especially due to the problem of TK-dependent drug resistance.

First, it is important to consider that in vitro drug susceptibility testing cannot always predict clinical responses. In five cases of ACV-resistant VZV infections treated with PFA, the clinical results were not predicted by drug susceptibilty testing. In fact, the authors observed healing despite the presence of PFA resistant

VZV strains and clinical failure although in vitro suscep-tibilty to PFA was observed. ${ }^{66}$ Drug susceptibilty testing also remains a time-consuming procedure and the majority of the therapeutic decisions have to be taken without test results.

Another important point to consider is that the drug-resistance of virus isolated from one given lesion may vary over time. Initially TK-deficient VZV strains can be isolated from hyperkeratotic lesions; after some time, however, samples from the same clinical lesions may produce functional TK proteins in viral culture. Hence, initial drug failure does not necessarily imply that this drug should be eliminated from the alternative therapeutic options.

Once diagnosed, intravenous or oral ACV is the first-line treatment at a dose of $30 \mathrm{mg} / \mathrm{kg}$ per day for 10 days; however, longer treatment is frequently required to achieve any response. When ACVresistance is suspected clinically, several therapeutic alternatives can be considered. A patient already treated with suppressive ACV doses could benefit from higher oral ACV dosages, or a change to the intravenous formulation of ACV (10 mg/kg per $8 \mathrm{~h})$; poor intestinal absorption of ACV should therefore be considered in the event of therapeutic failure. Another possibility is to use the newer oral formulations such as valaciclovir ( $3 \mathbf{x} 1000 \mathrm{mg} /$ day) that achieve a higher oral bioavailability than oral $\mathrm{ACV}$, or oral famciclovir ( $3 \mathbf{x} 500 \mathrm{mg}$ /day) that converts to penciclovir.

If increasing doses of a drug fail to produce clinical improvement after $\approx 1$ week, intravenous PFA (40-60mg/kgper $8 \mathrm{~h}$ )for 7-10 days may be attempted. , , As cross-resistance between TK-dependent drugs is not automatic, the use of oral famciclovir ( 3 x $500 \mathrm{mg} /$ day) could be considered as third therapeutic alternative in the case of a clinical suspicion of an ACV-resistant VZV strain.

Combining intravenous or oral ACV and PFA possibly remains the most reasonable treatment approach from a theoretical point of view. A successful outcome after 5 weeks with a combined treatment of intralesional interferon $\alpha-2 b$ (twice weekly) and topical $1 \%$ trifluorothy-midine solution (four times daily) has been described in a patient with ACV-resistant herpes zoster. Another treatment option in the event of suspected TK-dependent drug resistance consists of topical administration of the 
acyclic nucleoside phosphonate analogue cidofovir. , A73209 (Lobucavir) is an oral drug of the oxetanocin family of cyclobutyl nucleoside analogues. As its activity against TK-negative VZV strains is much lower than that against TK-positive strains ${ }^{76}$ it represents no practical therapeutic alternative in verrucous lesions associated with TK-dependent resistance.

\section{References}

[1] Grose C. Varicella zoster virus infections: chickenpox, shingles and varicella vaccine. In: Herpes Virus Infections Glaser R, Jones JF, eds. New York: Marcel Dekker Inc., 1994: 1117-85.

[2] Gilden DH, Mahalingham R, Dueland AM, Cohrs R. Herpes zoster: pathogenesis and latency. Prog Med Virol 1992; 39: 19-75.

[3] Arvin AM. Varicella-zoster virus. Clin Microbiol Rev 1996; 9: 361-81.

[4] Perronne C, Lazanas M, Leport C et al. Varicella in patients infected with the human immunodeficiency virus. Arch Dermatol 1990; 126: 1033-6.

[5 ] Cohen PR, Beltrani VP, Grossman ME. Disseminated herpes zoster in patients with human immunodeficiency virus infection. Am J Med 1988; 84: 1076-80.

[6] Nikkels AF, Delvenne P, Sadzot-Delvaux C et al. Distribution of varicella zoster virus and herpes simplex virus in disseminated fatal infections. J Clin Pathol 1996; 49: 243-8.

[7 ] Whitley RJ, Gnann JW. Editorial response: herpes zoster in patients with human immunodeficiency virus infection - an ever-expanding spectrum of disease. Clin Inf Dis 1995; 21: 989-90.

[8 ] Baselga E, Drolet BA, Segura AD, Leonardi CL, Esterly NB. Dermatomal lichenoid chronic graftvs-host disease following varicella-zoster infection despite absence of viral genome. J Cutan Pathol 1996; 23: 576-811.

[9 ] Nikkels AF, Sadzot-Delvaux C, Rentier B, Pierard-Franchimont C, Pierard GE. Low-productive alpha-herpesviridae infection in chronic lichenoid dermatoses. Dermatology 1998; 196: 442-6.

[10] Nikkels AF, Debrus S, Sadzot-Delvaux C, Piette J, Rentier B, Pierard GE. Localization of varicella-zoster virus nucleic acids and proteins in human skin. Neurology 1995; 45: 47-9.

[11] Muraki R, Iwasaki T, Sata T, Sato Y, Kurata T. Hair follicle involvement in herpes zoster: pathway of viral spead from ganglia to skin. Virchows Arch 1996; 428: 275-80.

[12] Weinberg JM, Mysliwiec A, Turiansky GW, Redfield R, James WD. Viral folliculitis. Arch Dermatol 1997; 133: 983-6.

[13] Jura E, Chadwick EG, Josephs SH et al. Varicella-zoster virus infections in children infected with human immunodeficiency virus. Pediatr Infect Dis J 1989; 8: 586-90.

[14] Tsao H, Tahan SR, Johnson RA. Chronic varicella zoster infection mimicking a basal cell carcinoma in an AIDS patient. J Am Acad Dermatol 1997; 36: 831-3.

[15] Jacobson MA, Berger TG, Fikrig S et al. Acyclovir-resistant varicella zoster virus infection after chronic oral acyclovir therapy in patients with the acquired immunodeficiency syndrome (AIDS). Ann Int Med 1990; 112: 187-91.

[16] Janier M, Hillion B, Baccard M et al. Chronic varicella zoster infection in acquired immunodeficiency syndrome. J Am Acad Dermatol 1988; 18: 584-5.

[17] Gallagher JG, Merigan TC. Prolonged herpes zoster infection associated with immunosuppressive therapy. Ann Int Med 1979; 91: 842-6.

[18] Disler RS, Dover JS. Chronic localized herpes zoster in the acquired immunodeficiency syndrome. Arch Dermatol 1990; 126: 1105-6.

[19] Grossman MC, Grossman ME. Chronic hyperkeratotic herpes zoster and human immunodeficiency virus infection. J Am Acad Dermatol 1993; 28: 306-8.

[20] Gilson IH, Barnett JH, Conant MA, Laskin OL, Williams J, Jones PG. Disseminated ecthymatous herpes varicella zoster virus infection in patients with acquired immunodeficiency syndrome. $J \mathrm{Am}$ Acad Dermatol 1989; 20: 637-42.

[21] Tronnier M, Plettenberg A, Meigel WN, Wolff HH. Recurrent verrucous herpes zoster in an HIV patient. Demonstration of the virus by immunofluorescence and electron microscopy. Eur J Dermatol 1994; 4: 604-7.

[22] Leboit PE, Limova M, Yen TSB, Palefsky JM, White CR, Berger TG. Chronic verrucous varicella zoster virus infection in patients with the acquired immunodeficiency syndrome. $\mathrm{Am} J$ Dermatopathol 1992; 14: 1-7.

[23] Hoppenjans WB, Bibler MR, Orme RL, Solinger AM. Prolonged cutaneous herpes zoster in acquired immunodeficiency syndrome. Arch Dermatol 1990; 126: 1048- 50.

[24] Colebunders R, Van Damme L, Van den Abbeele K, Fleerackers Y, Van den Enden E, Dockx P. 
Atypical varicella-zoster infection in persons with HIV infection. Acta Clin Belg 1994; 49: 104-7. [25] Bernard P, Obel N. Chronic ulcerating acyclovir-resistant varicella zoster virus in an AIDS patient. Scand J Inf Dis 1995; 27: 623-5.

[26] Leibowitz E, Kaul A, Rigaud M, Bebenroth D, Krasinski K, Borkowsky W. Chronic varicella zoster in a child infected with human immunodeficiency virus: case report and review of the literature. Cutis 1993; 49: 27-31.

[27] Vaughan-Jones SA, McGibbon DH, Bradbeer CS. Chronic verrucous varicella-zoster infection in a patient with AIDS. Clin Exp Dermatol 1994; 19: 327-9.

[28] Lokke-Jensen B, Weismann K, Mathiesen L, Thomsen HK. Atypical varicella-zoster infection in AIDS. Acta Derm Venereol 1993; 73: 123-5.

[29] Smith KJ, Skelton HG, Frissman DM, Angritt P. Verrucous lesions secondary to DNA viruses in patients infected with the human immunodeficiency virus in association with increased factor XIII-a positive dermal dendritic cells. J Am Acad Dermatol 1992; 27: 943-50.

[30] Aronson MD, Phillips CF, Gump DW, Albertini RJ, Phillips CA. Vidararbine therapy for severe herpesvirus infections: an unusual syndrome of chronic varicella and transient immunologic deficiency. J Am Med Assoc 1976; 235: 1339-42.

[31] Dolin R, Reichman RC, Mazur MH, Whitley RJ. Herpes zoster-varicella infections in immunosuppressed patients. Ann Int Med 1978; 89: 375-88.

[32] Nikkels AF, Pierard GE. Recognition and treatment of shingles. Drugs 1994; 48: 528-48.

[33] Snoeck R, Andrei G, De Clercq E. Current pharmacological approaches to the therapy of varicella-zoster virus infections: a guide to treatment. Drugs, 1999; 57: 187- 206.

[34] Snoeck R, De Clercq E. Herpesvirus infections in immuno-compromised patients. Cancer Treat Res 1995; 79: 149- 71.

[35] Ljungman P. Herpes virus infections in immunocompro-mised patients: problems and therapeutic interventions. Ann Med 1993; 25: 329-33.

[36] Veraldi Gnecchi L, Zorzi F. Verrucous-crusted herpes zoster in an immunocompetent patient. Acta Derm Venereol 1998; 78: 236-7.

[37] Pahwa S, Biron KK, Lim Wet al. Continuous varicella zoster infection associated with acyclovir resistance in a child with AIDS. J Am Med Assoc 1988; 260: 2879-82.

[38] Lim W, Sadick N, Gupta A, Kaplan M, Pahwa S. Skin diseases in children with HIV infection and their association with degree of immunosuppression. Int J Dermatol 1990; 29: 24-30.

[39] Prose NS. HIV infection in children. J Am Acad Dermatol 1990; 22: 1223-31.

[40] Tappero JW, Perkins BA, Wenger JD, Berger TG. Cutaneous manifestations of opportunistic infections in patients infected with human immunodeficiency virus. Clin Microbiol Rev 1995; 8: 44050.

[41] Alessi E, Cusini M, Zerboni R et al. Unusual varicella zoster virus infection in patients with the acquired immunodeficiency syndrome. Arch Dermatol 1988; 124: 1011-3.

[42] Smith KJ, Skelton HG, Yeager J et al. Cutaneous findings in HIV-1 positive patients: a 42-month study. J Am Acad Dermatol 1994; 31: 746-54.

[43] Manian FA, Kindred M, Fulling KH. Chronic varicella-zoster virus myelitis without cutaneous eruption in a patient with AIDS. report of a fatal case. Clin Inf Dis 1995; 21: 986-8.

[44] Zaal MJW, Maudgal PC, Rietveld E, Suir EPE. Chronic ocular zoster. Curr Eye Res 1991, 10 (Suppl.): 125-30.

[45] Nikkels AF, Rentier B, Pierard GE. Chronic varicella zoster virus skin lesions in patients with human immunodeficiency virus are related to decreased expression of gE and gB. J Infect Dis 1997; 176: $261-4$.

[46] Sadzot-Delvaux C, Debrus S, Nikkels AF, Piette J, Rentier B. Varicella-zoster virus latency in the adult rat is a useful model for human latent infection. Neurology 1995; 45: 18-20.

[47 ] Debrus S, Sadzot-Delvaux C, Nikkels AF, Piette J, Rentier B. Varicella-zoster virus gene 63 encodes an immediate-early protein that is abundantly expressed during latency. $J$ Virol 1995; 69: $3240-5$.

[48] Meier JL, Holman RP, Croen KD, Smialek JE, Straus S. Varicella-zoster virus transcription in human trigeminal ganglia. Virology 1993; 193: 193-200.

[49] Vafai A, Murray RS, Wellish M, Devlin M, Gilden D. Expression of varicella-zoster virus and herpes simplex virus in normal human trigeminal ganglia. Proc Natl Acad Sci USA 1988; 85: $2362-6$. [50] Mahalingham R, Wellish M, Cohrs R et al. Expression of protein encoded by varicella zoster virus open reading frame 63 in latently infected human ganglionic neurons. Proc Natl Acad Sci USA 1996; 93: 2122-4.

[51] Sadzot-Delvaux C, Thonard P, Schoonbroodt S, Piette J, Rentier B. Varicella-zoster virus induces apoptosis in cell culture. J Gen Virol 1995; 76: 2875-9. 
[52] Cohen JI. Infection of cells with varicella-zoster virus down-regulates surface expression of class I major histo-compatibility complex antigens. $J$ Inf Dis 1998; 177: 1390-3.

[53] Modiano P, Salloum E, Gillet-Terver MN et al. Acyclovir-resistant chronic cutaneous herpes simplex in Wiskott- Aldrich syndrome. Br J Dermatol 1995; 133: 475-8.

[54] Safrin S, McKinley G, McKeough M, Robinson D, Spruance SL. Treatment of acyclovir unresponsive cutaneous herpes simplex virus infection with topically applied SP-303. Antiviral Res 1994; 25: 185-92.

[55] Abeck D, Brandt O, Weichenthal M, Kowalzick L, Mensing H. Chronische mukokutane herpes simplex infektion. Auftreten im rahmen einer hepatisch bedingten immundefizienz. Hautarzt 1993; 44: 670-3.

[56] Beasley KL, Cooley GE, Kao GF et al. Herpes simplex vege-tans: atypical genital herpes infection in a patient with common variable immunodeficiency. J Am Acad Dermatol 1997; 37: 860-3. [57] Yeh V, Hopp ML, Goldstein NS, Meyer RD. Herpes simplex chronic laryngitis and vocal cord lesions in a patient with acquired immunodeficiency syndrome. Ann Otol Rhinol Laryngol 1994; 103: 726-31.

[58 ] Chin RH, Ross BC, Taylor KI, Yung AP, Johnson PD. Chronic meningitis due to herpes simplex virus in an immunocompetent host. Eur J Clin Microbiol Inf Dis 1996; 15: 650-3.

[59] Andrei G, Snoeck R, Reymen D et al. Comparative activity of selected antiviral compounds against clinical isolates of varicella-zoster virus. Eur J Clin Microbiol Infect Dis 1995; 14: 318-28.

[60] Nikkels AF, Debrus S, Sadzot-Delvaux C, Piette J, Rentier B, Pie'rard GE. Immunohistochemical identification of Varicella-Zoster Virus gene 63-encoded protein (IE63) and Late (gE) protein on smears and cutaneous biopsies: Implications for diagnostic use. J Med Virol 1995; 47: 342-7.

[61] Cavicchini S, Brezzi A, Alessi E. Ultrastructural findings in mucocutaneous infections of patients seropositive to HIV. Am J Dermatopathol 1993; 15: 320-5.

[62] Lyall EGH, Ogilvie MM, Smith NM, Burns S. Acyclovir resistant varicella zoster and HIV infection. Arch Dis Child 1994; 70: 133-5.

[63] Ljungman P. Herpesvirus infections in immunocompro-mised patients: problems and therapeutic interventions. Ann Med 1993; 25: 329-33.

[64] Gulick RM, Heath-Chiozzi M, Crumpacker CS. Varicella-zoster virus disease in patients with human immunodeficiency virus infection. Arch Dermatol 1990; 126: 1086-8.

[65] Linnemann C Jr, Biron KK, Hoppenjans Wet al. Emergence of acyclovir resistant varicella zoster virus in an AIDS patient on prolonged acyclovir therapy. AIDS 1990; 4: 577-9.

[66] Snoeck R, Gerard M, Sadzot-Delvaux C et al. Meningora-diculoneuritis due to acyclovir-resistant varicella zoster virus in an acquired immune deficiency syndrome patient. J Med Virol 1994; 42: 33847.

[67] Safrin S, Berger TG, Gilson I et al. Foscarnet therapy in five patients with AIDS and acyclovirresistant varicella-zoster virus infection. Ann Intern Med 1991; 115: 19- 21.

[68] Boivin G, Edelman CK, Pednault L, Talarico CL, Biron KK, Balfour HH. Phenotypic and genotypic characterization of acyclovir-resistant varicella-zoster viruses isolated from persons with AIDS. J Infect Dis 1994; 170: 68-75.

[69] Talarico CL, Phelps WC, Biron KK. Analysis of the thymi-dine kinase genes from acyclovirresistant mutants of varicella-zoster virus isolated from patients with AIDS.

J Virol 1993; 67: 1024-33.

[70] Sall RK, Kauffman L, Levy CS. Successful treatment of progressive acyclovir-resistant herpes simplex virus using intravenous foscarnet in a patient with the acquired immunodeficiency syndrome. Arch Dermatol 1989; 125: 1548-50.

[71] Fillet A-M, Visse B, Caumes E, Dumont B, Gentilini M, Huraux J-M. Foscarnet-resistant multidermatomal zoster in a patient with AIDS. Clin Inf Dis 1995; 21: 1348-9.

[72] Reusser P. Herpesvirus resistance to antiviral drugs: a review of the mechanisms, clinical importance and therapeutic options. J Hosp Infect 1996; 33: 235-48.

[73] Balfour HH, Benson C, Braun J et al. Management of acyclovir-resistant herpes simplex and varicella-zoster virus infections. J Acquir Immune Defic Syndr 1994; 7: 254-60.

[74] Rossi S, Whitfeld M, Berger TG. The treatment of acyclovir-resistant herpes zoster with trifluorothymidine and interferon alpha. Arch Dermatol 1995; 131: 24-6.

[75] Martinez CM, Luks-Golger DB. Cidofovir use in acyclovir-resistant herpes infection. Ann Pharmacother 1997; 31: 1519-21.

[76 Alder J, Mitten M, Norbeck D, Marsh K, Kern ER, Clement J. Efficacy of A-73209, a potent orally active agent against VZV and HSV infections. Antiviral Res 1994; 23: 93-105. 